D. R. Marr

\begin{tabular}{|c|c|c|}
\hline $\begin{array}{l}\text { Operated by the } \\
\text { Westinghouse } \\
\text { Hanford Company }\end{array}$ & $\begin{array}{l}\text { A Subsidiary of } \\
\text { Westrighnuse Electtic } \\
\text { Corporation }\end{array}$ & $\begin{array}{l}\text { Tor the United States } \\
\text { Energy Research and } \\
\text { Development Administration } \\
\text { Contract No EY } 76-C 142170\end{array}$ \\
\hline
\end{tabular}




\section{DISCLAIMER}

This report was prepared as an account of work sponsored by an agency of the United States Government. Neither the United States Government nor any agency Thereof, nor any of their employees, makes any warranty, express or implied, or assumes any legal liability or responsibility for the accuracy, completeness, or usefulness of any information, apparatus, product, or process disclosed, or represents that its use would not infringe privately owned rights. Reference herein to any specific commercial product, process, or service by trade name, trademark, manufacturer, or otherwise does not necessarily constitute or imply its endorsement, recommendation, or favoring by the United States Government or any agency thereof. The views and opinions of authors expressed herein do not necessarily state or reflect those of the United States Government or any agency thereof. 


\section{DISCLAIMER}

Portions of this document may be illegible in electronic image products. Images are produced from the best available original document. 


\title{
CRITICALITY ANALYSIS FOR \\ FFTF FUEL ASSEMBLIES AND FUEL PINS
}

R. J. Morford and D. R. Marr

\begin{abstract}
A series of calculations is presented assessing the criticality aspects of specific configurations of FTR fuel. Results for regularly spaced arrangements of fuel pins or fuel assemblies as a function of spacing in each of four media (water, Mobiltherm, sodium, or air) are given. This information is intended to be of a broad general nature conservatively applicable both to normal fuel configurations likely to be encountered in the operation of the FFTF and to accident condition configurations postulated for criticality review purposes.
\end{abstract}


$\underline{\text { Page }}$

LIST OF FIGURES. . . . . . . . . . . . . iv

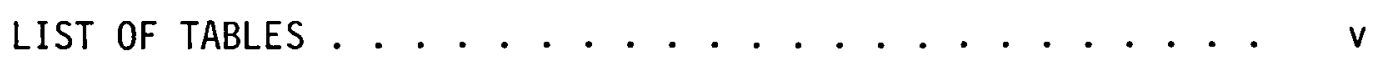

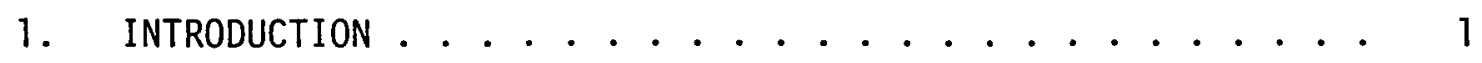

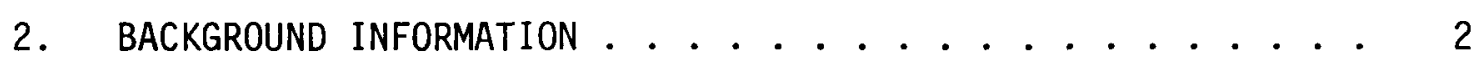

2.1 KENO. . . . . . . . . . . . . . 2

2.2 2DBS. . . . . . . . . . . . . . 3

2.3 HAMMER. . . . . . . . . . . . . . 4

2.4 Material Compositions . . . . . . . . . 4

2.4.1 Outer Driver Fuel Assembly (Fuel Region Only). . 4

2.4.1.1 Fuel Composition. ........ 4

2.4.1.2 Stainless Steel Composition
In The Active Fuel Zone ...... 5

2.4.2 Sodium In Active Fuel Zone (Per Assembiy). . . 5

2.4.3 Mobiltherm Composition ........ 5

$2.4 .4210 \# / \mathrm{FT}^{3}$ Magnetite Concrete Composition. . . . 5

2.5 Cross Section Sets Used . . . . . . . . . 6

2.5.1 FTR Set 300-S. .......... 6

2.5 .2 FTR Set 300............... 7

2.5.3 Hanson and Roach Cross Sections. ...... . 7

2.5.4 4-Group Cross Sections ......... 8

3. RESULTS. . . . . . . . . . . . . . . . . . 8

3.1 Criticality Calculations For Outer Driver Fuel

Assemblies................ 8

3.2 Fuel Pins In Water and Mobiltherm ........ 14

3.3 Outer Driver Fuel Pins In Sodium and Air. . . . . 15

4. FFTF FACILITIES AND EQUIPMENT. . . . . . . . . 22

4.1 Core Component Conditioning Stations (CCCS) . . . . 22

4.2 Bottom Loading Transfer Cask (BLTC) . . . . . . . 22

4.3 Interim Decay Storage (IDS) . . . . . . . . 23 


\section{TABLE OF CONTENTS (Cont'd)}

Page

4.4 Closed Loop Ex-Vessel Machine (CLEM). . . . . . . . 23

4.5 In-Vessel Handling Maching (IVHM) and In-Vessel Storage Module (IVSM) . . . . . . . . 24

4.6 Interim Examination and Maintenance (IEM) Cel1. . . . 24

4.7 Test Assembly Conditioning Station (TACS) . . . . . 26

4.8 Cask Loading Station. . . . . . . . . . . . 26

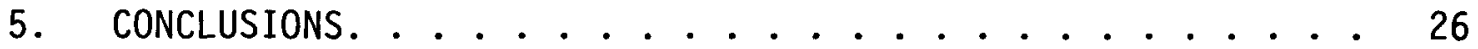

REFERENCES . . . . . . . . . . . . . . 28 


\section{LIST OF FIGURES}

Figure

Page

1 Geometry That Was Found To Be Critical By A 2DBS

Critical Radius Search, For Fuel In Sodium

(Corresponds to 34.5 Outer Driver Fuel Assemblies). . . . . 10

2 Geometry That Was Found To Be Critical By A 2BDS

Critical Radius Search, For Fuel In Air

(Corresponds to 38.2 Outer Driver Fuel Assemblies). . . . 11

3 KENO Geometry That Was Found To Be Critical For

4.715" Fuel Assembly Pitch in Sodium

(Corresponds to 29 Fuel Assemblies) . . . . . . . . . 12

$4 \quad$ KENO Geometry That Was Found To Be Critical For

4.715" Fuel Assembly Pitch in Air

(Corresponds to 33 Fuel Assemblies) . . . . . . . . 13

5 Geometry That Was Found To Be Critical By A 2DBS

Critical Radius Search, For Fuel Pins Without Wire Wrap

in Sodium (Corresponds to 3532 Pins). . . . . . . . . . 17

6 Geometry That Was Found To Be Critical By A 2DBS

Critical Radius Search, For Tightly-Spaced Wire-Wrapped

Fuel Pins in Sodium (Corresponds to 5493 Pins). . . . . . 18

7 Geometry That Was Found To Be Critical By A 20BS

Critical Radius Search, For Fuel Pins With A $0.370 "$

Lattice Pitch in Sodium (Corresponds to 12,280 Pins). . . . 19

8 Geometry That Was Found To Be Critical By A 20BS

Critical Radius Search, For Fuel Pins Without Wire

Wrap in Air (Corresponds to 3571 Pins). . . . . . . . 20

9 Geometry That Was Found To Be Critical By A 2DBS

Critical Radius Search, For Tightly-Spaced Wire-Wrapped

Fuel Pins In Air (Corresponds to 5929 Pins) . . . . . . 21 


\section{LIST OF TABLES}

$\underline{\text { Table }}$

$\underline{\text { Page }}$

$1 \quad$ Number of Outer Driver Assemblies for Criticality in

Mobiltherm for Specific Geometries . . . . . . . . . . 9

2 Number of Outer Driver Assemblies for Criticality

in Sodium. . . . . . . . . . . . . . . . . . 9

3 Number of Outer Driver Assemblies for Criticality

in Air........................ 9

4 Pin Experiment ................. 14

5 Fuel Pin Criticality in Mobiltherm .......... 15

6 Fuel Pin Criticality in Sodium . . . . . . . . . 16

7 Fuel Pin Criticality in Air. . . . . . . . . . . 16 


\section{INTRODUCTION}

Fuel used in FTR consists of mixed plutonium-uranium oxide. The heavy metal composition is 25 to 30 percent plutonium by weight; thus, fuel items that would normally be handled in operation of the plant contain considerable quantities of fissile material. For instance, the ${ }^{239} \mathrm{Pu}$ content of an outer driver subassembly is about 7.8 kilograms. This is far in excess of the amount of ${ }^{239} \mathrm{Pu}$ that is required to form a critical assembly. Only 5.2 kilograms of ${ }^{239} \mathrm{Pu}$ metal, reflected by water, are critical. Yet an intact FTR fuel assembly by virtue of its geometry and the poison effect of other included materials is safely subcritical even in the event of flooding with a hydrogenous moderator. However, if disassembly is a possibility, one FTR fuel assembly contains more than enough pins for criticality if those pins become properly spaced in a hydrogenous medium.

Because of the necessity of handling at least one fuel assembly in many of the FFTF facilities, a batch limit based on the minimum critical mass is thus impractical. Rather, limits that included constraints on the configuration are employed. Criticality reviews of such facilities must then evaluate the potential for redistribution into a more reactive configuration.

It is the purpose of this document to present the criticality properties of a set of reference configurations that were selected for applicability in a conservative fashion to many of the FFTF facilities. Configurations were selected to be applicable for postulated accident conditions as well as for the conditions normally expected in operation of the FFTF.

Fuel forms normally encountered in FTR operation will be intact fuel assemblies and assemblages of individual fuel pins. Fuel forms other than these are not considered here. Such other forms could only occur under postulated accident conditions or during special handling; they will not be encountered in normal FFTF operations. 
Fuel will normally be immersed in either a gas atmosphere or sodium. Criticality data are provided for each of these media. In addition, data are provided for two hydrogenous materials, water and a hydrocarbon called Mobiltherm, which is typical of the coolants that may be used in some equipment. In considering accident possibilities, as is required in the criticality review process, it might be postulated that these moderating materials would flood a fuel facility and greatly increase the reactivity.

The reflection and moderating properties of the material surrounding the fuel array also affect criticality. The most likely materials in FFTF would be sodium or one of the various concretes found in the shield walls. Under accidental flooding conditions, one would need to consider the possibility of a water or Mobiltherm reflector. Other candidates would be steel, which is used as cell wall liners and tank walls, or a composite material representing the axial reflectors inherent in the pins together with possible interspersed water or Mobiltherm.

\section{BACKGROUND INFORMATION}

The computer codes, material compositions, and cross section sets used are described in this section.

\subsection{KENO $^{(1)}$}

KENO is a 3-D multigroup Monte Carlo criticality program. It contains a special geometry package which allows easy description of systems composed of cylinders, spheres, and cuboids (rectangular parallelepipeds) arranged in any order with only one restriction. This restriction is that each geometrical region must be described as completely enclosing all regions interior to it.

The need to accurately determine the criticality condition of systems of fissile materials in irregular geometrical shapes prompted the development of a Monte Carlo program for this purpose. While $S_{n}$ type programs such as ANISN and DOT have been used extensively for criticality calculations, they are restricted to fairly simple geometries. KENO was developed to satisfy the need for a more general geometrical treatment. 
The ease of describing the geometry of a system was another important consideration in the development of KENO. It was essential that the geometrical input be simple enough that input data errors be minimized.

The scattering treatment used in KENO assumes that the differential neutron scattering cross section can be represented by a $P_{1}$ Legendre polynomial. Absorption of neutrons in KENO is not allowed. Instead, at each collision point of a neutron tracking history the weight of the neutron is reduced by the absorption probability. When the neutron weight has been reduced below a specified point for the region in which the collision occurs, Russian roulette is played to determine if the neutron's history is to be terminated at that point or if the neutron is to survive with an increased weight. Splitting of high weight neutrons is allowed in order to minimize the variance in $k_{\text {eff }}$ for systems with regions of widely varying average weights.

Output from KENO consists of the $k_{\text {eff }}$ for the system plus an estimate of its standard deviation and the leakage, absorption, and fissions for each energy group plus the totals for all groups.

KENO is one of the most accepted criticality programs in use at this time, and its results compare favorably with experiments (see References 2 through 4 ).

\subsection{DBS $^{(5)}$}

2DBS is a two-dimensional, multigroup, diffusion theory burnup code. 2DBS is designed explicitly for use in fast reactor analysis. Eigenvalues are computed by standard source-iteration techniques. Group rebalancing and successive over-relaxation with line inversion are used to accelerate convergence. Adjoint solutions are obtained by inverting the input data and redefining the source terms.

Criticality searches can be performed on buckling, material concentrations, and region dimensions. Alpha and $k_{\text {eff }}$ can be used as parametric eigenvalues. Criticality searches can be performed during burnup to compensate for fuel depletion. 
Many 2DBS criticality and reactivity calculations for sodium-cooled fast-flux systems have been made and compared to various reactor experiments with excellent results (see References 6 through 12).

\subsection{HAMMER (13)}

The HAMMER system, developed jointly by Brookhaven National Laboratory and Savannah River Laboratory, consists of a set of linked physics codes which are modified versions of THERMOS (a thermalization transport theory code), MUFT (fast neutron spectrum code), ZUT+TUZ (a program for calculation of resonance integrals), and FOG (one-dimensional diffusion equation codes). This battery of codes has been applied to both $\mathrm{D}_{2} 0$-uranium and light water lattices with very good results. Furthermore, each of these codes has been proven individually through extensive use. The object of the HAMMER code was to el iminate the burdensome task of preparing redundant sets of input for the above mentioned codes, and to standardize the mathematical model used to calculate the many different lattices.

The HAMMER code was used to simulate critical approach and exponential experiments with prototype FFTF driver fuel pins in water (see Reference 14). A comparison of these experiments with the HAMMER calculations is contained in Section 3.2. The calculations are very close to the experimental results and are conservative for the most reactive fuel pin spacings.

\subsection{Material Compositions}

2.4.1 Outer Driver Fuel Assembly (Fuel Region Only)

\subsubsection{Fuel Composition}

$\begin{array}{lr}\text { Pu-239 } & 7.84 \mathrm{Kg} \\ \text { Pu-240 } & 1.06 \mathrm{Kg} \\ \text { Pu-241 } & 0.15 \mathrm{Kg} \\ \text { Pu-242 } & 0.02 \mathrm{Kg} \\ \text { U-238 } & 23.88 \mathrm{Kg} \\ \text { U-235 } & 0.17 \mathrm{Kg} \\ \text { Oxygen } & 4.34 \mathrm{Kg}\end{array}$




\subsubsection{Stainless Steel Composition In The Active Fuel Zone}

$\begin{array}{lr}\mathrm{Mn} & 0.39 \mathrm{Kg} \\ \mathrm{Si} & 0.20 \mathrm{Kg} \\ \mathrm{Cr} & 3.36 \mathrm{Kg} \\ \mathrm{Ni} & 2.37 \mathrm{Kg} \\ \mathrm{Mo} & 0.49 \mathrm{Kg} \\ \mathrm{Fe} & 12.92 \mathrm{Kg}\end{array}$

\subsubsection{Sodium In Active Fuel Zone (Per Assembly)}

$\mathrm{Na}-4.49 \mathrm{Kg}$ (includes all sodium attributable to one assembly including $1 / 2$ the sodium between adjacent assemblies for a fuel assembly pitch of 4.715 inches)

$\mathrm{Na}-4.14 \mathrm{Kg}$ (contained within the fuel assembly itself)

\subsubsection{Mobiltherm Composition}

$$
\begin{aligned}
& H-0.099 \mathrm{~g} / \mathrm{cm}^{3} \\
& \mathrm{C}-0.884 \mathrm{~g} / \mathrm{cm}^{3}
\end{aligned}
$$

\section{$2.4 .4 \quad 210 \# / \mathrm{FT}^{3}$ Magnetite Concrete Composition}

$\mathrm{H}-0.011 \mathrm{~g} / \mathrm{cm}^{3}$

$0-1.075 \mathrm{~g} / \mathrm{cm}^{3}$

$\mathrm{Mg}-0.023 \mathrm{~g} / \mathrm{cm}^{3}$

A1 $-0.094 \mathrm{~g} / \mathrm{cm}^{3}$

$\mathrm{Si}-0.120 \mathrm{~g} / \mathrm{cm}^{3}$

$\mathrm{Ca}-0.235 \mathrm{~g} / \mathrm{cm}^{3}$

$\mathrm{Ti}-0.094 \mathrm{~g} / \mathrm{cm}^{3}$

$V-0.006 \mathrm{~g} / \mathrm{cm}^{3}$

Fe $-1.703 \mathrm{~g} / \mathrm{cm}^{3}$ 


\subsection{Cross Section Sets Used}

\subsubsection{FTR Set 300-S ${ }^{(15)}$}

\begin{tabular}{cccccc} 
Group & Energy Boundaries (ev) & Group & Energy Boundaries (ev) \\
\cline { 1 - 3 } 1 & $6.065+6$ to $1.000+7$ & 22 & $1.234+3$ to $2.035+3$ \\
2 & $3.679+6$ to $6.065+6$ & 23 & $7.485+2$ to $1.234+3$ \\
3 & $2.231+6$ to $3.679+6$ & 24 & $4.540+2$ to $7.485+2$ \\
4 & $1.353+6$ to $2.231+6$ & 25 & $2.754+2$ to $4.540+2$ \\
5 & $8.208+5$ to $1.353+6$ & 26 & $1.670+2$ to $2.754+2$ \\
6 & $4.979+5$ to $8.208+5$ & 27 & $1.013+2$ to $1.670+2$ \\
7 & $3.877+5$ to $4.979+5$ & 28 & $6.144+1$ to $1.013+2$ \\
8 & $3.020+5$ to $3.877+5$ & 29 & $3.727+1$ to $6.144+1$ \\
9 & $1.832+5$ to $3.020+5$ & 30 & $2.260+1$ to $3.727+1$ \\
10 & $1.111+5$ to $1.832+5$ & 31 & $1.371+1$ to $2.260+7$ \\
11 & $6.738+4$ to $1.111+5$ & 32 & $8.315+0$ to $1.371+1$ \\
12 & $4.087+4$ to $6.738+4$ & 33 & $5.043+0$ to $8.315+0$ \\
13 & $2.554+4$ to $4.087+4$ & 34 & $3.059+0$ to $5.043+0$ \\
14 & $1.989+4$ to $2.554+4$ & 35 & $1.855+0$ to $3.059+0$ \\
15 & $1.503+4$ to $1.989+4$ & 36 & $1.125+0$ to $1.855+0$ \\
16 & $9.119+3$ to $1.503+4$ & 37 & $6.826-1$ to $1.125+0$ \\
17 & $5.531+3$ to $9.119+3$ & 38 & $4.140-1$ to $6.826-1$ \\
18 & $3.355+3$ to $5.531+3$ & 39 & $2.511-1$ to $4.140-1$ \\
19 & $2.840+3$ to $3.355+3$ & 40 & $1.523-1$ to $2.511-1$ \\
20 & $2.404+3$ to $2.840+3$ & 41 & $9.237-2$ to $1.523-1$ \\
21 & $2.035+3$ to $2.404+3$ & 42 & THERMAL
\end{tabular}


2.5 .2 FTR Set $300(16)$

\section{0-Group Energy Structure}

Group Energy Boundaries (ev) Group Energy Boundaries (ev)

$16.065+06$ to $1.000+07 \quad 16 \quad 9.119+03$ to $1.503+04$

$23.679+06$ to $6.065+06 \quad 17 \quad 5.531+03$ to $9.119+03$

$32.237+06$ to $3.679+06 \quad 18 \quad 3.355+03$ to $5.531+03$

$41.353+06$ to $2.231+06 \quad 192.840+03$ to $3.355+03$

$58.209+05$ to $1.353+06 \quad 202.404+03$ to $2.840+03$

$64.979+05$ to $8.209+05 \quad 212.035+03$ to $2.404+03$

$73.877+05$ to $4.979+05 \quad 22 \quad 1.234+03$ to $2.035+03$

$83.020+05$ to $3.877+05 \quad 23 \quad 7.485+02$ to $1.234+03$

$9 \quad 1.832+05$ to $3.020+05 \quad 24 \quad 4.540+02$ to $7.485+02$

$10 \quad 1.111+05$ to $1.832+05 \quad 25 \quad 2.754+02$ to $4.540+02$

$116.738+04$ to $1.111+05 \quad 26 \quad 1.301+02$ to $2.754+02$

$124.087+04$ to $6.738+04 \quad 27 \quad 6.144+01$ to $1.301+02$

$132.554+04$ to $4.087+04 \quad 28 \quad 1.371+01$ to $6.144+01$

$14 \quad 1.989+04$ to $2.554+04 \quad 29 \quad 6.826-01$ to $1.371+01$

$15 \quad 1.503+04$ to $1.989+04 \quad 30 \quad 2.520-2$

\subsubsection{Hanson and Roach Cross Sections}

16-Group Energy Structure

Group Energy Boundaries (ev) Group Energy Boundaries (ev)

$\begin{array}{llrl}1 & 3.00+6 \text { to } \infty & 9 & 1.00+2 \text { to } 5.50+2 \\ 2 & 1.40+6 \text { to } 3.00+6 & 10 & 3.00+1 \text { to } 1.00+2 \\ 3 & 9.00+5 \text { to } 1.40+6 & 11 & 1.00+1 \text { to } 3.00+1 \\ 4 & 4.00+5 \text { to } 9.00+5 & 12 & 3.00+0 \text { to } 1.00+1 \\ 5 & 1.00+5 \text { to } 4.00+5 & 13 & 1.00+0 \text { to } 3.00+0 \\ 6 & 1.70+4 \text { to } 1.00+5 & 14 & 4.00-1 \text { to } 1.00+0 \\ 7 & 3.00+3 \text { to } 1.70+4 & 15 & 1.00-1 \text { to } 4.00-1 \\ 8 & 5.50+2 \text { to } 3.00+3 & 16 & \text { THERMAL }\end{array}$




\subsubsection{4-Group Cross Sections}

(Generated by HAMMER From HAMLET 54-Group and THERMOS 30-Group)

$\begin{array}{cll}\text { Group } & \frac{\text { Energy Boundaries }}{1} & 8.21+05 \text { to } 1.00+07 \\ 2 & 5.53+03 \text { to } 8.21+05 \\ 3 & 6.29-01 \text { to } 5.53+03 \\ 4 & 0.00 & \text { to } 6.29-01\end{array}$

\section{RESULTS}

\subsection{Criticality Calculations for Outer Driver Fuel Assemblies}

2DBS criticality calculations were made for several specific outer driver fuel assembly configurations of interest with a Mobiltherm moderator. The fuel assemblies were assumed to have infinite length and were reflected by Mobiltherm (where a reflector is applicable). The 4-group cross sections generated by HAMMER were used. The results of these calculations are given in Table 1.

Both 2DBS and KENO were used to determine the number of outer driver fuel assemblies required for criticality in sodium and air when reflected by $210 \# / \mathrm{FT}^{3}$ magnetite concrete (for conservatism) and with various triangular lattice pitches. The 2DBS analyses with FTR Set 300 s cross sections were based on the geometries shown in Figures 1 and 2 with a radius search made for a fixed $k_{\text {eff }}$ of 1.00. Each run was made with the fuel region homogenized to correspond to a given fuel assembly pitch in either air or sodium. After the critical homogenized "fuel" radius was determined by 2DBS, the equivalent number of fuel assemblies was determined by hand. As indicated, 34.5 and 38.2 outer driver fuel assemblies were required for criticality in sodium and air respectively.

The same type of calculations were made using KENO with the 16-group Hanson and Roach cross sections instead of using 2DBS. The geometries that were found to be critical are shown in Figures 3 and 4 , and the number of 


\section{Table 1}

NUMBER OF OUTER DRIVER ASSEMBLIES FOR CRITICALITY IN MOBILTHERM ${ }^{b}$ FOR SPECIFIC GEOMETRIES

\section{LATTICE PITCH (in.)}

4.715 (touching, flat-to-flat)

5.44 (touching, vertex-to-vertex)
CRITICAL NUMBER OF ASSEMBLIES

10

8 Subcritical

Table 2

NUMBER OF OUTER DRIVER ASSEMBLIES FOR CRITICALITY IN SODIUM ${ }^{a b}$

\section{LATTICE PITCH (in.)}

4.715 (touching)

210

$>10$
CRITICAL NUMBER

OF ASSEMBLIES

$$
29
$$

$\infty$

Subcritical

$\underline{\text { Table } 3}$

NUMBER OF OUTER DRIVER ASSEMBLIES FOR CRITICALITY IN AIR ${ }^{\text {ab }}$

\section{LATTICE PITCH (in.)}

4.715 (touching)

थ10

$>10$
CRITICAL NUMBER

OF ASSEMBLIES

33

$\infty$

Subcritical

a Fully reflected by $210 \# / \mathrm{FT}^{3}$ Concrete.

b Fue] contains $27.36 \mathrm{w} / \mathrm{o} \mathrm{Pu}--87.5 \% \mathrm{Pu}^{239}$, $11 \% \mathrm{Pu}^{240}, 1.5 \% \mathrm{Pu}^{241}$. 


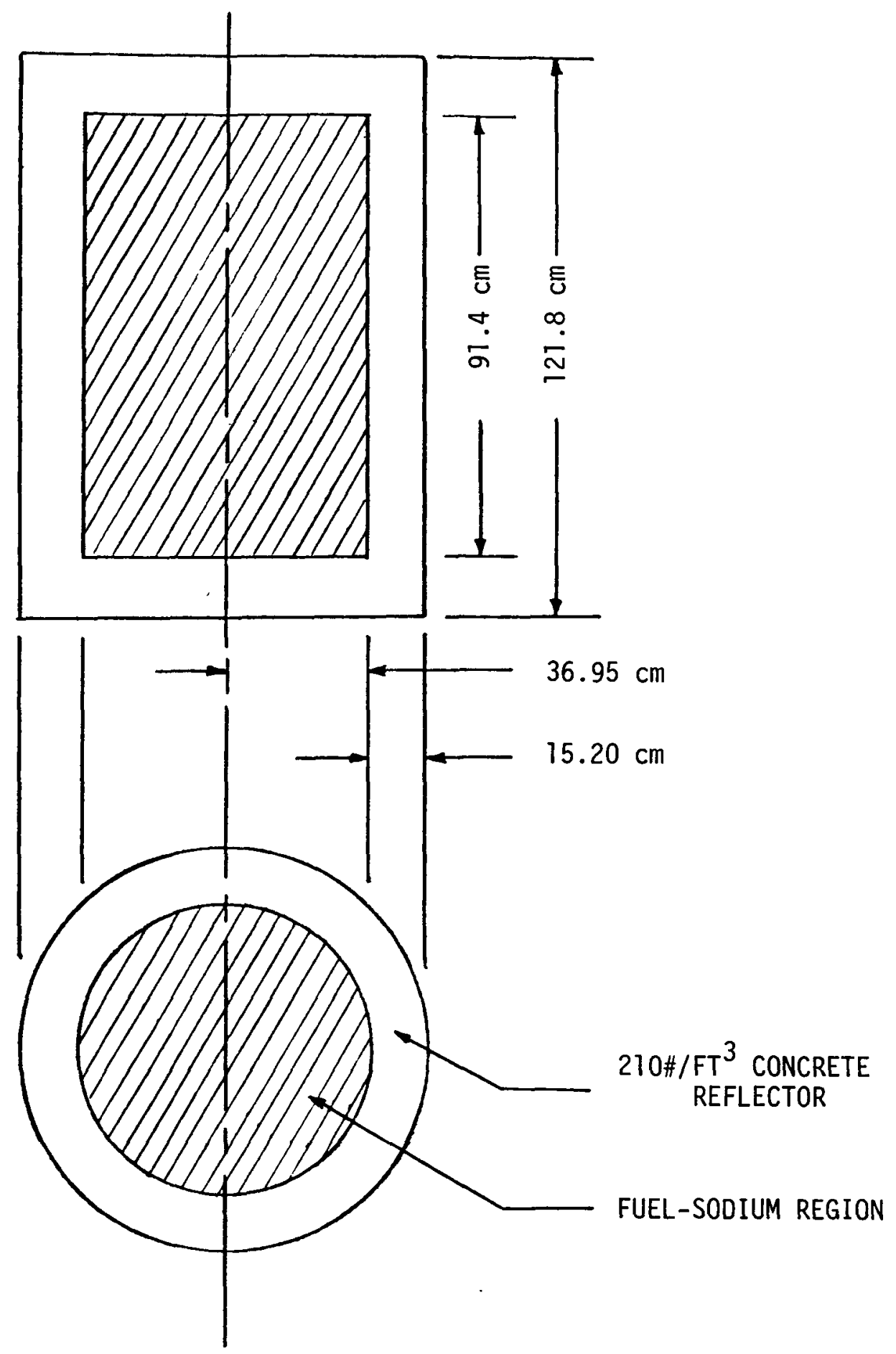

FIGURE 1 - GEOMETRY THAT WAS FOUND TO BE CRITICAL BY A 2DBS CRITICAL RADIUS SEARCH, FOR FUEL IN SODIUM (CORRESPONDS TO 34.5 OUTER DRIVER FUEL ASSEMBLIES) 


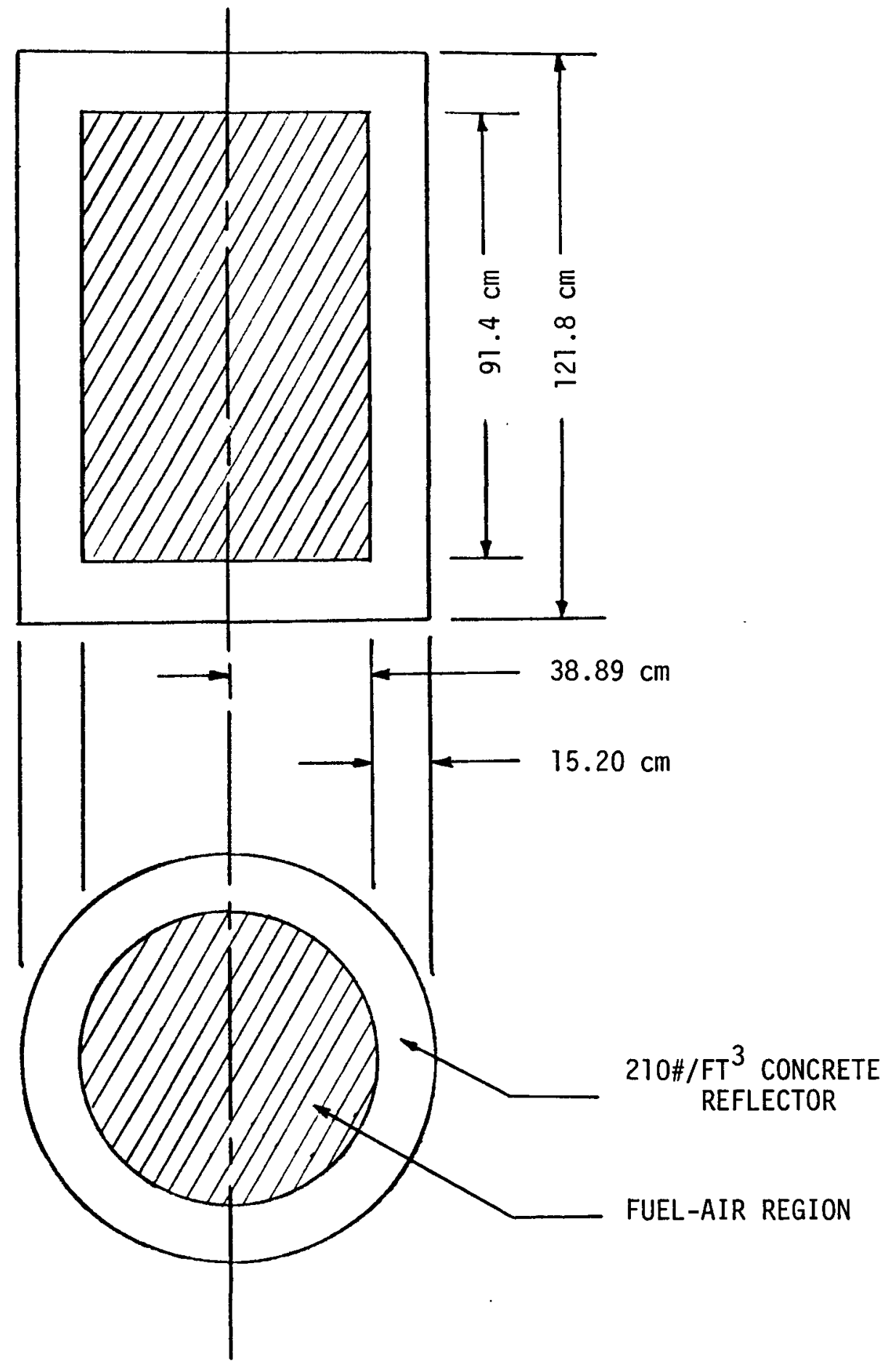

FIGURE 2 - GEOMETRY THAT WAS FOUND TO BE CRITICAL BY A 2DBS CRITICAL RADIUS SEARCH, FOR FUEL IN AIR (CORRESPONDS TO 38.2 OUTER DRIVER FUEL ASSEMBLIES) 


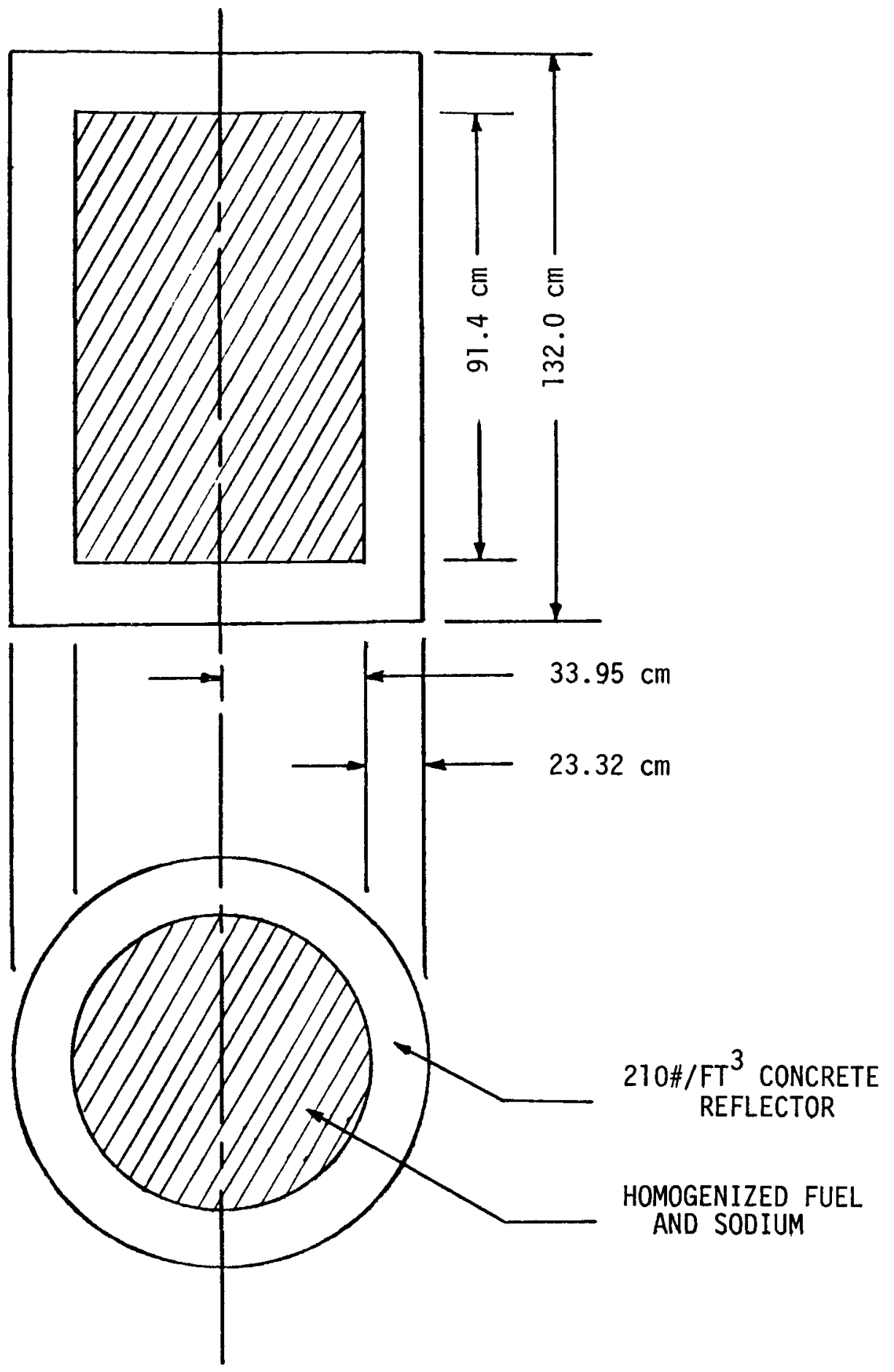

FIGURE 3 - KENO GEOMETRY THAT WAS FOUND TO BE CRITICAL FOR 4.715" FUEL ASSEMBLY PITCH IN SODIUM (CORRESPONDS TO 29 FUEL ASSEMBLIES) 


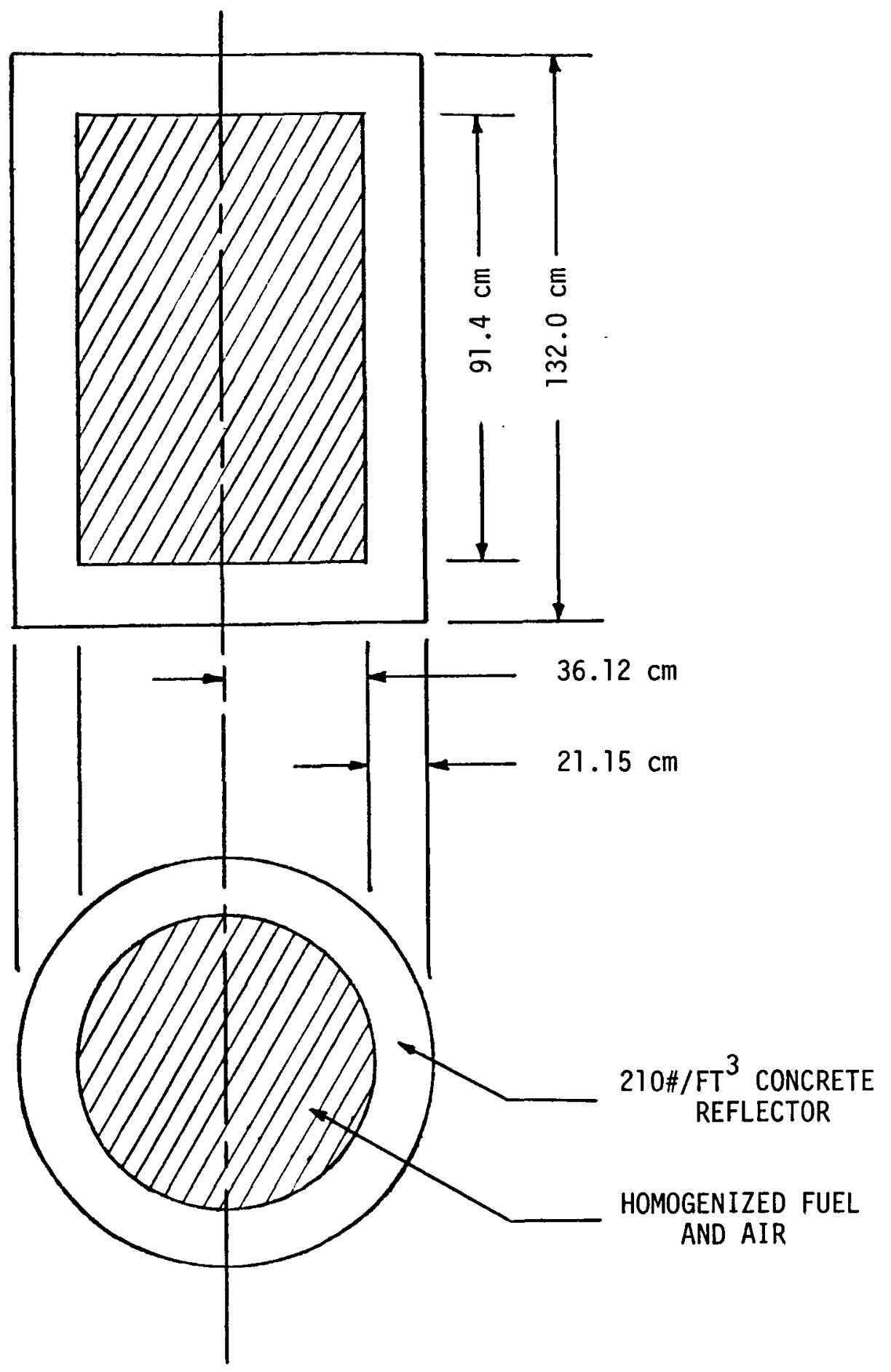

FIGURE 4 - KENO GEOMETRY THAT WAS FOUND TO BE CRITICAL FOR 4.715" FUEL ASSEMBLY PITCH IN AIR (CORRESPONDS TO 33 FUEL ASSEMBLIES) 
fuel assemblies corresponding to fuel regions of the radii shown are given in Tables 2 and 3 . The KENO values should be assumed correct in all cases in order to be conservative.

\subsection{Fuel Pins In Water and Mobiltherm}

The HAMMER code with the 84-group THERMOS-U0026/HAMLET-SRLNEW cross sections $(17)$ was used to analyze a critical experiment involving FTR-like fuel pins in water $(14)$. A comparison of HAMMER and experimental results is given in Table 4 .

\section{Table 4}

\section{PIN* EXPERIMENT}

\begin{tabular}{|c|c|c|}
\hline & Critical & Number \\
\hline Pitch (in.) & Exp. & Calc. \\
\hline $\begin{array}{l}0.450 \\
0.600 \\
0.779 \\
0.900 \\
1.039 \\
1.200 \\
1.350\end{array}$ & $\begin{array}{l}417 \\
219 \\
156 \\
150 \\
165 \\
232 \\
410\end{array}$ & $\begin{array}{l}445 \\
217 \\
154 \\
146 \\
158 \\
217 \\
454\end{array}$ \\
\hline
\end{tabular}

* $25 \mathrm{w} / \mathrm{o} \mathrm{PuO}_{2}, 27$ in. long, 0.230 in. diameter. $\mathrm{Pu}$ composition is $86.5 \%{ }^{239} \mathrm{Pu}, 11.7 \%{ }^{240} \mathrm{Pu}$, $1.7 \%{ }^{241} \mathrm{Pu}, 0.2 \%{ }^{242} \mathrm{Pu}$.

HAMMER (with the 84-group cross section set) was also used to calculate the minimum number of FFTF outer-driver-fuel-pins required for criticality in Mobiltherm as a function of lattice spacing. The results of these runs are given in Table 5. Similar calculations were made for FFTF fuel pins in water, which turned out to be less reactive than with Mobiltherm. 


\section{Table 5}

\section{FUEL ${ }^{b}$ PIN CRITICALITY IN MOBILTHERM ${ }^{a}$}

\section{LATTICE PITCH (in.)}

0.286 (wire wrap spacing)

0.30

0.35

0.40

0.45

0.60

0.90

1.05

1.20

1.40

1.50

1.80
CRITICAL NUMBER OF FUEL PINS

a Pins in triangular pitch, surrounded by mobiltherm reflector.

b Outer driver fuel enrichment $\left(27.37 \mathrm{w} / \mathrm{O} \mathrm{PuO}_{2}\right)$ with $87.5 \%{ }^{239} \mathrm{Pu}, 11 \% 240 \mathrm{Pu}, 1.5 \%{ }^{241} \mathrm{Pu}$.

\subsection{Outer Driver Fuel Pins in Sodium and Air}

The minimum number of fuel pins required for criticality in sodium for various lattice pitches was determined with 2DBS using the FTR Set 300 S cross sections. The 2DBS analyses were based on the geometries shown in Figures 5, 6, and 7 for triangular pitches of 0.230" (clad-to-clad), 0.286" (wire wrap spacing), and $0.370^{\prime \prime}$ respectively. A similar run (geometry not shown) was made for a lattice pitch of $0.572 "$. In all these cases a radius search was made for a fixed $k_{\text {eff }}$ of 1.00 . After the critical homogenized fuel radius was determined by 2DBS, the equivalent number of fuel pins corresponding to this radius was determined by hand. The results of these calculations are shown in Table 6. 


\section{Table 6}

FUEL $^{b}$ PIN CRITICALITY IN SODIUM ${ }^{a}$

LATTICE PITCH (in.)

0.230 (clad-to-clad)

0.286 (wire wrap spacing

0.370

0.572
CRITICAL NUMBER

OF FUEL PINS

$$
\begin{array}{r}
3,532 \\
5,493 \\
12,280 \\
>56,000
\end{array}
$$

a Triangular pitch, surrounded by $210 \# / \mathrm{FT}^{3}$ concrete reflector.

b Fuel contains $27.37 \mathrm{w} / \mathrm{O} \mathrm{Pu}--87.5 \%{ }^{239} \mathrm{Pu}, 11 \%{ }^{240} \mathrm{Pu}$, $1.5 \% 241 \mathrm{Pu}$.

Similar 2DBS calculations were made for fuel pins in air. The geometries used for these calculations are shown in Figures 8 and 9 . Once again, the fuel zone radi $i$ shown in Figures 8 and 9 correspond to the minimum number of pins required for criticality in air at a pitch of $0.230^{\prime \prime}$ and $0.286^{\prime \prime}$, respectively. The results of these runs are given in Table 7 .

\section{Table 7}

FUEL $^{b}$ PIN CRITICALITY IN AIR

\section{LATTICE PITCH (in.)}

0.230 (clad-to-clad)

0.286 (wire wrap spacing)
CRITICAL NUMBER OF FUEL PINS

3,571

5,929

a Triangular pitch, surrounded by $210 \# / \mathrm{FT}^{3}$ concrete reflector.

b Fuel contains $27.37 \mathrm{w} / 0 \mathrm{Pu}--87.5 \%{ }^{239} \mathrm{Pu}, 11 \%{ }^{240} \mathrm{Pu}$, $1.5 \%{ }^{241} \mathrm{Pu}$. 


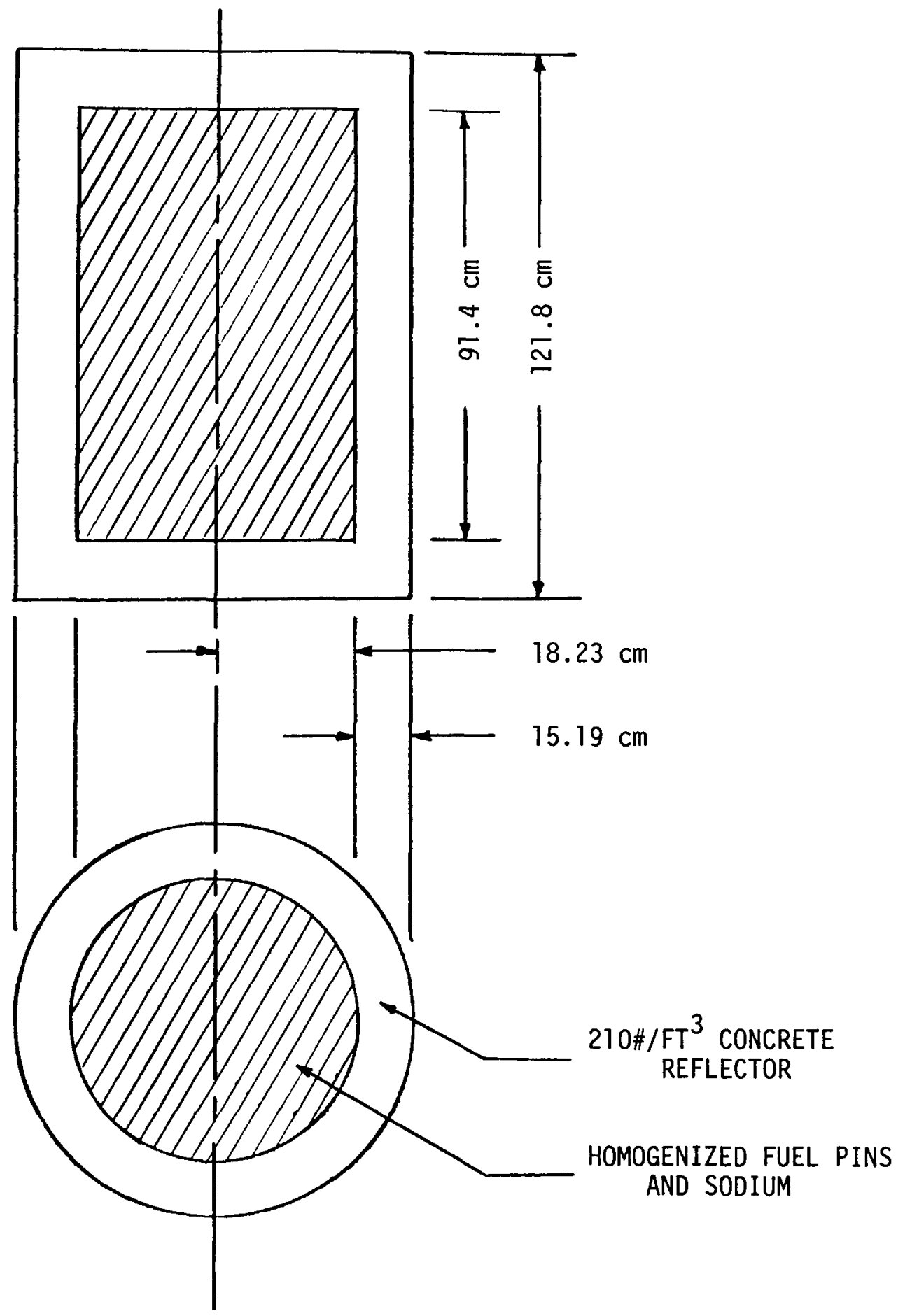

FIGURE 5 - GEOMETRY THAT WAS FOUND TO BE CRITICAL BY A 2DBS CRITICAL RADIUS SEARCH, FOR FUEL PINS WITHOUT WIRE WRAP IN SODIUM (CORRESPONDS TO 3532 PINS) 


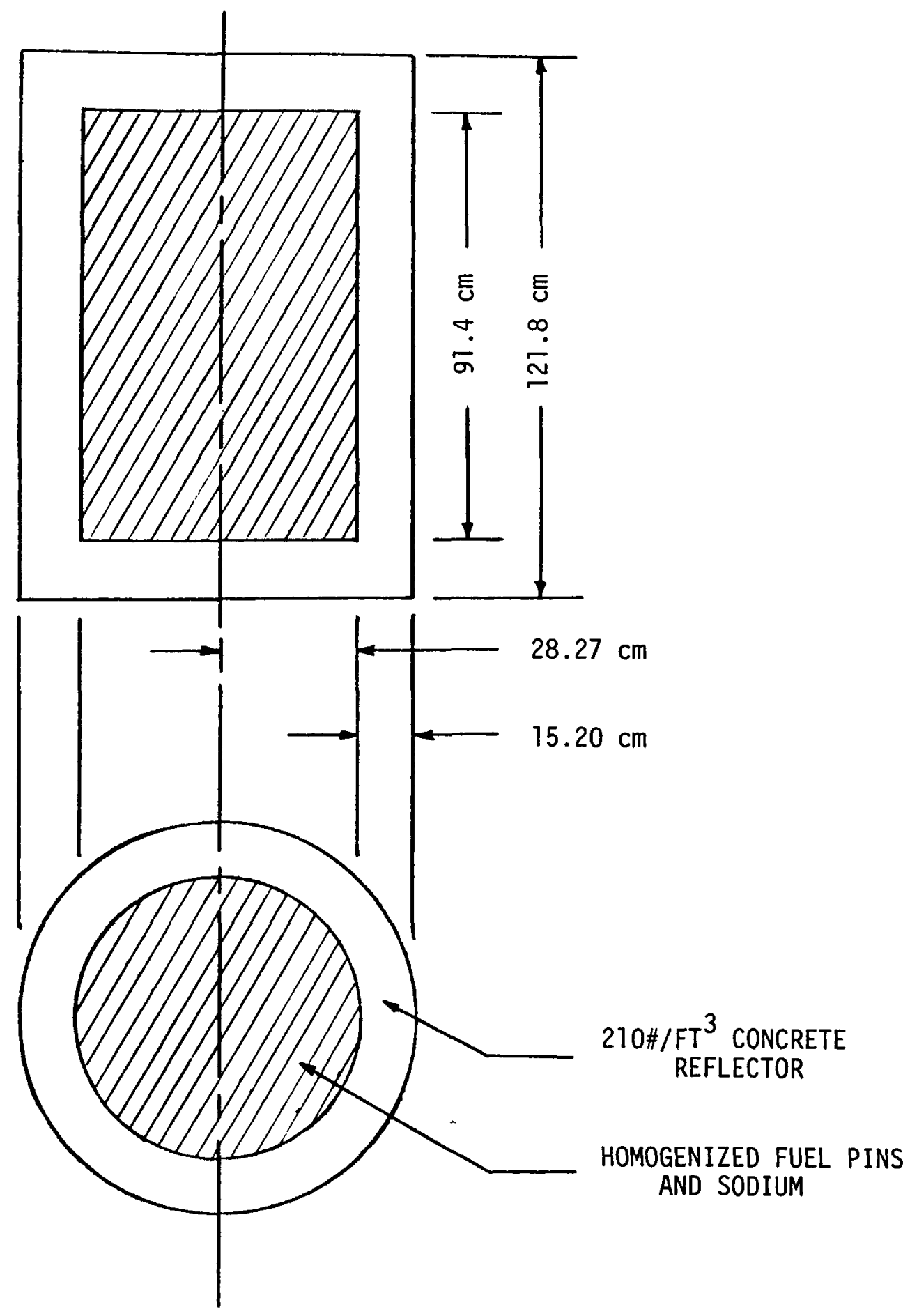

FIGURE 6 - GEOMETRY THAT WAS FOUND TO BE CRITICAL BY A 2DBS CRITICAL RADIUS SEARCH, FOR TIGHTLY-SPACED WIRE-WRAPPED FUEL PINS IN SODIUM (CORRESPONDS TO 5493 PINS) 


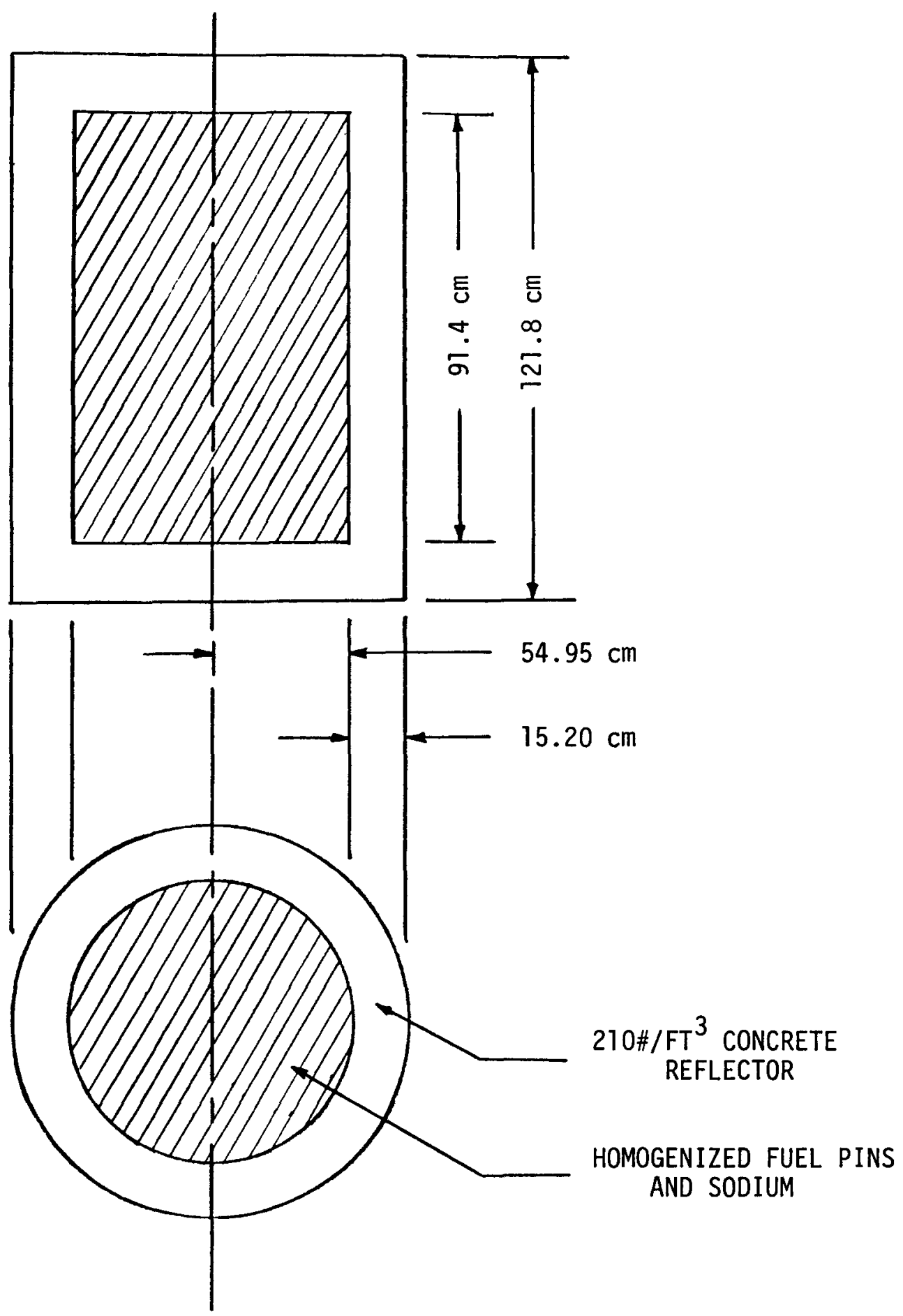

FIGURE 7 - GEOMETRY THAT WAS FOUND TO BE CRITICAL BY A 2DBS CRITICAL RADIUS SEARCH, FOR FUEL PINS WITH A $0.370^{\prime \prime}$ LATTICE PITCH IN SODIUM (CORRESPONDS TO 12,280 PINS) 


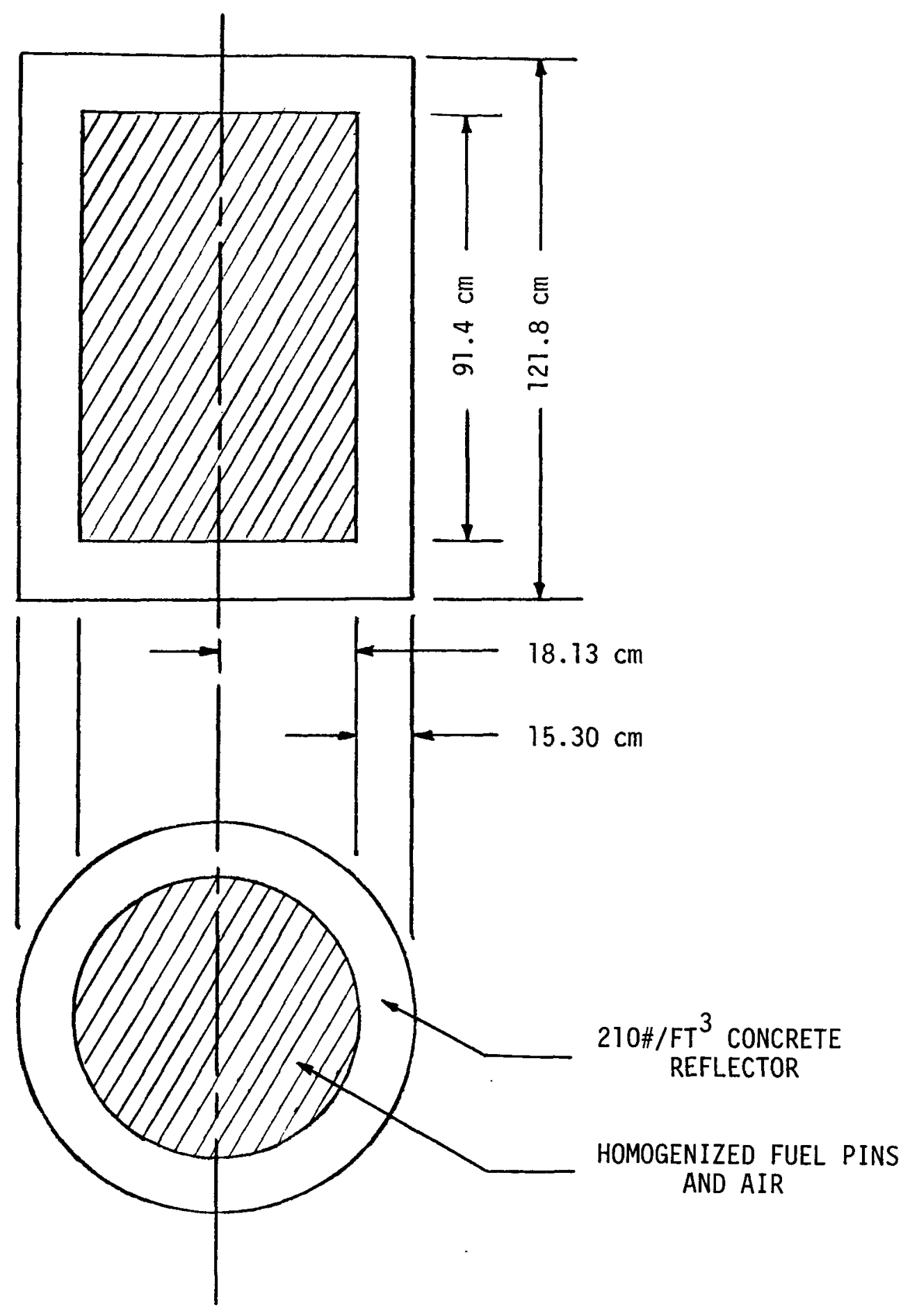

FIGURE 8 - GEOMETRY THAT WAS FOUND TO BE CRITICAL BY A 2DBS CRITICAL RADIUS SERACH, FOR FUEL PINS WITHOUT WIRE WRAP IN AIR

(CORRESPONDS TO 3571 PINS) 


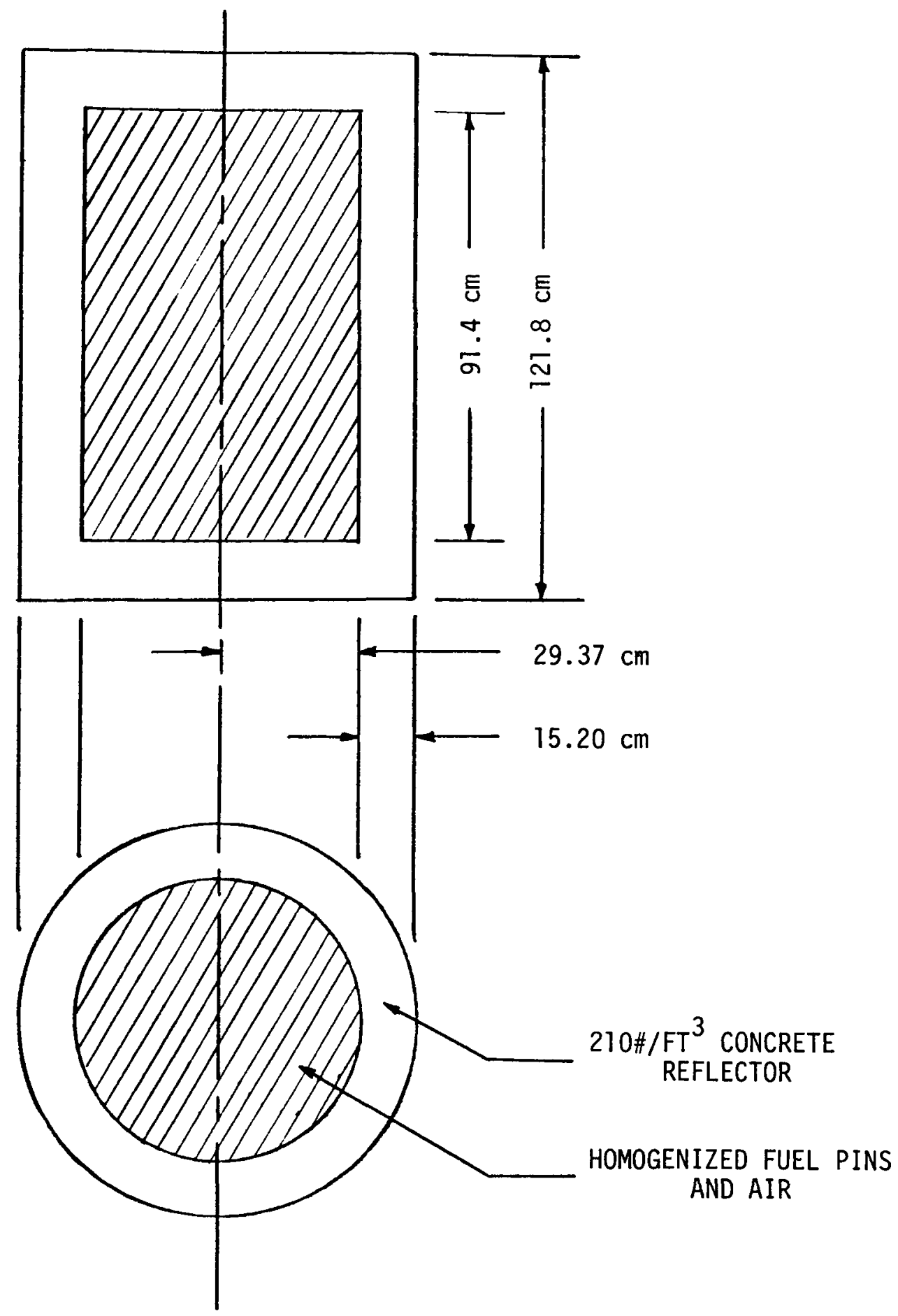

FIGURE 9 - GEOMETRY THAT WAS FOUND TO BE CRITICAL BY A 2DBS CRITICAL RADIUS SEARCH, FOR TIGHTLY-SPACED WIRE-WRAPPED FUEL PINS IN AIR (CORRESPONDS TO 5929 PINS) 


\section{FFTF FACILITIES AND EQUIPMENT}

The following sections discuss each fuel handling machine and facility from the standpoint of criticality safety.

\subsection{Core Component Conditioning Stations (CCCS)}

New fuel assemblies will arrive at the site in individual containers, which will be off-loaded at a receiving location in the reactor service building. The containers will be moved through the equipment airlock into the containment building to an unloading space adjacent to the CCCS. At this location, the fuel assemblies, one at a time, will be removed from the shipping container, inspected, logged into the inventory control system, and inserted into a CCCS for inerting and preheating. Each CCCS location consists of a well in the operating floor, with the diameter of the well making it impossible to insert more than one assembly at a time. A single fuel assembly in a CCCS would be subcritical even in the unlikely event the station might be flooded with Mobiltherm. Irradiated fuel pins being removed from the IEM cell following disassembly of the duct are to be housed in sealed containers and placed in the CCCS Transfer Cell (CCCS, south) by using the Closed Loop Ex-Vessel Machine (CLEM) and then removed by the Bottom Loading Transfer Cask (BLTC) from Containment. The number of pins in the sealed container will be restricted, and the sealed container will prevent the introduction of moderating materials such as Mobiltherm, in the unlikely event of an accident.

\subsection{Bottom Loading Transfer Cask (BLTC)}

The preheated and inerted fuel assembly will be transferred from the CCCS to the Interim Decay Storage (IDS) using the BLTC. A floor valve (FV) is placed over both the CCCS opening and the IDS opening to maintain argon atmosphere control during the transfer. The BLTC is first mated to the FV over the CCCS to pick up the fuel assembly. The size of the BLTC barrel, together with the lifting mechanism, makes it impossible to lift more than a single fuel assembly into the BLTC. Flooding of the BLTC would appear to be impossible, but in any event the contained fuel assembly would remain subcritical. 


\subsection{Interim Decay Storage (IDS)}

The IDS facility consists of a vessel with an upper section about $12 \mathrm{ft}$. in diameter and $20 \mathrm{ft}$. tall, contiguous with a lower extension section that is about $6 \mathrm{ft}$. in diameter and about $20 \mathrm{ft}$. long. This vessel houses a rotatable storage rack that contains 112 positions in the outer portion for storage of core components, and 10 positions in the middle portion for storage of test assemblies. The vessel is full of sodium which is maintained at a temperature of about $500^{\circ} \mathrm{F}$. The new fuel assembly, previously preheated in the CCCS within an argon atmosphere, will be lowered from the BLTC through the FV into a sodium-filled Core Component Pot (CCP) that resides in one of the 112 core component storage tubes. The storage tubes in the rotatable storage rack are sized to contain a single CCP in each tube. The spacing of the storage tubes provides mechanical assurance that the spacing of the fuel will be maintained within defined limits. Extensive criticality calculations were undertaken for the IDS and established that the fully loaded system will have an effective multiplication factor of about $0.73 \pm 0.04$ based on the plutonium inventory in fresh outer driver fuel assemblies for the first few cores. Subcriticality is achieved by the spacing of the fuel in the steel and sodium matrix. No accident conditions were identified that could compact the overall spacing significantly. Insertion and removal of either test or fuel assemblies was calculated not to increase the effective multiplication of the system significantly.

\subsection{Closed Loop Ex-Vessel Machine (CLEM)}

Fuel is transferred from the IDS to the reactor vessel through use of the CLEM. This is a large shielded machine weighing about 240 tons and extending about $62 \mathrm{ft}$. vertically above the operating floor. The CLEM, which is designed to dissipate up to $10 \mathrm{kWt}$ of decay heat associated with a fuel assembly, is moved by a 125-ton transporter on a 40-ft. span rail system. The fuel is transported in CLEM while remaining in a sodium-filled CCP. The grapple drive system in CLEM is designed to pick up only a CCP or a test assembly. Because of the grapple assembly and the diameter of 
the CLEM opening, only one fuel containing assembly can be placed in CLEM; and as has been shown (see Table 1), one assembly remains subcritical even if immersed in a good moderator such as Mobiltherm.

\subsection{In-Vessel Handling Machine (IVHM) and In-Vessel Storage Module (IVSM)}

Fuel is lowered into the reactor vessel from the CLEM through a Fuel Transfer Port (FTP) while in a sodium-filled CCP. The CCP remains in the IVSM transfer location while the IVHM removes the fuel assembly from the CCP and transports the fuel to either a reactor core position for irradiation or to an IVSM position. There are three IVSM locations within the reactor vessel (RV), one in each sector between the core barrel and the RV. Each module contains storage locations for up to 19 core components. When decay heat is less than $10 \mathrm{~kW}$ per assembly, fuel can be moved directly from the core to a transfer location by the IVHM and removed to IDS using the CLEM. If decay heat rates exceed $10 \mathrm{kWt}$ per subassembly, the fuel will be transferred from the core to an IVSM storage position using the IVHM. Fuel stored in IVSM will remain there until decay heating is less than $10 \mathrm{kWt}$ per subassembly, at which time it can be moved to the transfer location when the reactor is shut down, using the IVHM, for subsequent removal by the CLEM. Calculations indicate that at least 29 outer driver assemblies in an optimum array are required to achieve a critical configuration: therefore, the 19 positions in an IVSM provide a safe array, even when fully loaded. Interaction between the core and these modules and also between modules does not increase reactivity significantly because of the intervening materials. It is not possible to place two assemblies in a single IVSM position, and the mechanical structure maintains a minimum spacing between assemblies. The IVSM and IVHM are adequately designed from the standpoint of criticality considerations.

\subsection{Interim Examination and Maintenance (IEM) Cell}

The IEM Cell has a basic functional objective of providing a reliable means of retrieving data from irradiated fuel while maintaining controlled environmental conditions. In addition, the IEM Cell processes irradiated fuel for off-site shipment, and performs limited maintenance on contaminated or radioactive plant equipment. The sealed shielded cell is equipped with 
manipulators, cranes, viewing windows, and specialized remote handling equipment. The IEM Cell is designed to accommodate individual sodiumwetted irradiated fuel assemblies with decay heats of up to $7 \mathrm{kWt}$. Irradiated fuel is brought to the IEM Cell using the CLEM and is transferred through either of two smaller diameter valves in the IEM Cell ceiling valve.

The maximum decay heat removal capability of the argon atmosphere in the IEM Cell is $18 \mathrm{kWt}$, and the number of irradiated fuel assemblies to be located within the IEM Cell at any one time is to be limited administratively to three. The logistics of the confined cell space will likely limit this to two assemblies. However, for the rated cell limit of three assemblies, one could be disassembled with pins packaged for transfer, one could be in the process of being disassembled, and the third one, although intact, could be in transit within the cell. Individual fuel pins are to be nondestructively examined, including dimensional checks, weighing, gamma scanning, visual inspection, and photography. Disassembly of the fuel will take place in the IEM Cell annex, where the pins will also undergo examination and will be stored temporarily. Only the pins of a single fuel element will be in the annex; the other two fuel assemblies or packaged pins will be stored in the main part of the cell or will be entering or leaving the cell through the ceiling valve. No criticality problem is associated with the fuel assemblies or packaged pins, since these will remain safely subcritical under any potential accident condition.

Administrative control will be required to account for all pins from the disassembled fuel element. Since the 217 pins in an assembly are more than adequate to form a critical assembly if appropriately spaced and moderated (see Table 5), administrative controls will be required to maintain safe storage of the individual pins, and to assure that no moderator can inundate the stored pins. When examination of the pins is complete, the pins are to be placed in a container and sealed for subsequent off-site shipment. The number of pins in the sealed container is limited 
to assure thermal safety and is more than adequate to assure criticality safety under any moderating or other accident condition.

\subsection{Test Assembly Conditioning Station (TACS)}

The TACS performs an analogous function to the CCCS for the longer fuel test assemblies. There are 27 storage positions in the TACS, with an inert gas atmosphere.

Design features disallow insertion of assemblies into interstitial positions thus limiting the number of contained assemblies to 27 . As the critical number of outer driver fuel assemblies in gas is 33 when tightly packed (Table 3 ), this facility is subcritical as designed for the present enrichment and quantity of fuel in outer driver fuel assemblies.

In the unlikely event of Mobiltherm flooding (Table 1), analyses show TACS would remain subcritical because of the large spacing (14-1/2 in.) between assemblies, a spacing assured by the mechanical design.

\subsection{Cask Loading Station}

The Cask Loading Station, located in the reactor service building (RSB), includes equipment for handling irradiated reactor core components and equipment. Irradiated fuel exits from the Containment Building through the equipment airlock in the BLTC. The fuel is transferred from the BLTC to the LMFBR Shipping Cask which is positioned in the Cask Loading Station. Off-site shipment of FFTF fuel will comply with the Cask criticality requirements. The BLTC single core component transfer operation at the Cask Loading Station is judged to be inherently safe from the standpoint of criticality.

\section{CONCLUSIONS}

In all areas in which fuel will be handled at the FFTF, the fixed geometry will safely keep the fuel subcritical. However, because a fuel assembly can be disassembled in the IEM Cell, tight administrative controls must be exercised to assure safe geometry. If the pins were grouped with the proper spacing after disassembly and the cell flooded with a good 
moderator such as water or Mobiltherm, a critical assembly could be formed. Therefore, geometric controls will be exercised on disassembled pin bundles to make sure that a potentially critical fuel pin configuration is not formed in the very remote circumstance that flooding were to occur. 


\section{REFERENCES:}

1. G. E. Whitesides and N. F. Cross, KENO - A Multigroup Monte Carlo Criticality Program, CTC-5, Union Carbide Corp.

2. R. D. Carter, G. R. Kiel, and K. R. Ridgeway, Criticality Handbook, Vol. II, ARH 600, Atlantic Richfield Hanford Co., Richland, WA, May 1969.

3. C. M. Hopper and G. R. Handley, Validation of the KENO Code for Nuclear Criticality Safety Calculations of Moderated Low Enriched Uranium Systems, Y-1948, Union Carbide Corp., Oak Ridge, Tenn., June 1974.

4. D. Dickinson and G. E. Whitesides, The Monte Carlo Method for Array Criticality Calculations, Nuclear Technology, August 1976.

5. D. R. Marr, A User's Manual for 2DBS, A Diffusion Theory Shielding Code, BNWL-1291, Battelle Northwest Laboratory, Richland, WA, February 1970.

6. R. M. Fleischman, Evaluation of the Modified Source Multiplication Technique for Subcritical Reactivity Assessments in FTR, HEDL-TME 74-53, Appendix A, Hanford Engineering Development Laboratory, Richland, WA, October 1974.

7. J. W. Daughtry, Calculations of $\mathrm{Eu}_{2} \mathrm{O}_{3}$ and $\mathrm{B}_{4} \mathrm{C}$ Worths in the Fast Test Reactor Engineering Mockup, HEDL-TME 75-34, Appendix A, Hanford Engineering Development Laboratory, Richland, WA, June 1975.

8. K. D. Dobbin and J. W. Daughtry, Central Fuel Worth in the Fast Test Reactor (FTR) Engineering Mockup, HEDL-TME 75-52, Hanford Engineering Development Laboratory, Richland, WA, June 1975.

9. J. W. Daughtry and K. D. Dobbin, FFTF Test Loading Effects - Analysis of Experiments in the FTR Engineering Mockup Critical, HEDL-TME 76-34, Hanford Engineering Development Laboratory, Richland, WA, August 1976.

10. J. W. Daughtry and K. D. Dobbin, High ${ }^{240} \mathrm{Pu}$ Fuel Worth in the Fast Test Reactor Engineering Mockup, HEDL-TME 76-31, Hanford Engineering Development Laboratory, Richland, WA, May 1976.

11. K. D. Dobbin and J. W. Daughtry, Analysis of Control Rod Interaction Experiments in the FTR Engineering Mockup Critical, HEDL-TME 76-52, Hanford Engineering Development Laboratory, Richland, WA, March 1976.

12. K. D. Dobbin and J.W. Daughtry, Analys is of Small-Sample Reactivity Worths in the Fast Test Reactor Engineering Mockup Critical, HEDL-TME 76-87, Hanford Engineering Development Laboratory, Richland, WA, December 1976. 
13. J. E. Suick and H. C. Honeck, The HAMMER System, DP-1064, E. J. Du Pont de Ne Mours and Co., Aiken, South Carolina (1967).

14. C. L. Brown and C. A. Rogers, Critical Approach and Exponential Experiments with Prototype FFTF Driver Fuel Pins in Water, Trans. Am. Nucl. Soc., 13, 663, 1970.

15. R. B. Kidman and R. E. Schenter, FTR Set 300-S, Multigroup Cross Sections for FTR Shielding Calculations, HEDL-TME 71-184, Hanford Engineering Development Laboratory, Richland, WA, December 1971.

16. R. E. Schenter, R. B. Kidman, and J. V. Nelson, FTR Set 300, Multigroup Cross Sections for FTR Design, HEDL-TME 71-153, Hanford Engineering Development Laboratory, Richland, WA, October 1971.

17. H. Toffer, UNIVAC 1108 HAMMER-HANFORD Version Supplementary User's Note, United Nuclear Industries, June 1973. 